\title{
FAKTOR-FAKTOR YANG BERHUBUNGAN DENGAN PEMBERIAN ASI EKSLUSIF PADA IBU YANG MELAKSANAKAN IMD DI BPM KHAIRANI ASNITA TAHUN 2015
}

\author{
Widya Juliarti \&Atifa Merlin
}

Email: widya_juliarti@yahoo.co.id

\begin{abstract}
Exclusive breastfeeding is the only breast milk given to infants without additional other liquids without solid food for six additional 6 months. Breastfed babies have a greater chance of early success exclusive breastfeeding. Based on preliminary studies in December 2015 in BPM Khairani Asnita, in the know of 20 people who gave birth to entirely successfully perform IMD but only 3-5 people who exclusively breastfed rest melanjutlan with formula. The purpose of this study to determine the factors associated with exclusive breastfeeding in mothers who carry BPM Khairani Asnita IMD in Riau Province in 2015. This type of research is analytic survey with cross sectional study design. The population is mothers delivered in BPM Khairani Asnita and do IMD with babies aged 16-12 months amounted to 60 people. The sampling technique used is total sampling. Bivariate data analysis with test of chi-square test. Based on the results of the univariate analysis showed that the majority of mothers breastfeed as much as $56.7 \%$ exclusive. The results of the bivariate analysis pvalue values obtained for each variable with $\alpha 0.05$ is for attitude $p=0.000$, husband support the value of $p=0.004, p=$ success IMD 0,007, maternal age the value of $p=0.031$. The conclusion of this study that the attitude of the mother, husband support, the success of IMD and the mother's age is a factor that affects exclusively breastfeeding mothers do IMD in BPM Khairani Asnita Year 2015. It is expected the next BPM Khairani Asnita able to reassure patients who visit or maternity there for can give only breast milk until the child is 6 months old, as well as explaining the benefits of exclusive breastfeeding for babies and mothers.
\end{abstract}

Keywords: Factors, Exclusive Breastfeeding, Mother Who Carry IMD, BPM Khairani Asnita

\section{PENDAHULUAN}

Air susu ibu (ASI) adalah suatu emulsi lemak dalam larutan protein, laktosa dan garam-garam anorganik yang sekresi oleh kelenjar mamae ibu, yang berguna sebagai makanan bagi bayinya. Fungsi ASI untuk memenuhi kebutuhan gizi bayi dan melindunginya dalam melawan kemungkinan serangan penyakit. Keseimbangan zat-zat gizi dalam ASI berada pada tingkat terbaik. Pada saat yang sama, ASI juga sangat kaya akan sari-sari makanan yang mempercepat pertumbuhan sel-sel otak dan perkembangan sistem saraf. Makanan-makanan tiruan untuk bayi yang diramu menggunakan teknologi canggih sekalipun tidak mampu menandingi keunggulan ASI (Rosita, 2008).

Melihat besarnya manfaat dari ASI maka pada tahun 1992 WHO/UNICEF mengeluarkan protokol tentang Inisiasi Menyusui Dini (IMD) sebagai salah satu dari Evidence for the ten step to successful breastfeeding yang harus diketahui setiap tenaga kesehatan. Segera setelah bayi di lahirkan, bayi di letakan di dada atau perut atas ibu selama paling sedikit satu jam untuk memberi kesempatan pada bayi untuk mencari dan menemukan puting susu ibunya (Prawirohardjo, 2010).

IMD tidak hanya menyukseskan pemberian ASI ekslusif. Lebih dari itu, terlihat hasil yang nyata yaitu menyelamatkan nyawa bayi, jika semua bayi di dunia segera setelah lahir diberi kesempatan menyusu sendiri dengan membiarkan kontak kulit ibu ke kulit bayi setidaknya selama satu jam, maka satu jiwa bayi dapat di selamatkan (Roesli, 2008). Bayi yang di beri kesempatan untuk menyusu dini akan mempunyai kesempatan lebih berhasil menyusui eksklusif dan mempertahankan menyusu daripada yang menunda dari yang menyusu dini (Jenny \& J.s. Sondakh, 2013).

Setiap tahun di dunia ada sekitar 4 juta bayi meninggal karena penyakit infeksi terkait dengan perilaku ibu yang tidak memberikan kolostrum dan air susu ibu (ASI) eksklusif pada bayi. Pemberian ASI eksklusif merupakan salah satu program untuk menurunkan angka kematian neonatal (Morhason-Bello et al., 2009).

Dengan disyahkan kebijakan pemerintah: Peraturan Pemerintah (PP) no.33 tahun 2012 mengenai ASI eklusif yang mewajibkan 
pelaksanaan IMD di semua layanan kesehatan dan pemberian ASI Eklusif pada bayi menjadi pendukung rasa aman dan nyaman ibu di berbagai tempat layanan sehingga diharapkan penurunan AKB dapat tercapai sesuai target, karena IMD merupakan salah satu faktor keberhasilan ibu dalam memberikan ASI secara ekslusif (Inisiasi Menyusu Dini \& Pemberian ASI Eklusif, PP No.33 tahun 2013).

Secara nasional cakupan pemberian ASI eksklusif sebesar 52,3\% belum mencapai target nasional $80 \%$. Hanya provinsi Nusa Tenggara Barat sebesar 84,7\% (Profil Kesehatan Indonesia, 2014).

Persentase pemberian ASI eksklusif pada bayi 0-6 bulan di Provinsi Riau pada tahun 2013 sebesar 51,2\%. Kabupaten dengan cakupan pemberian ASI Eksklusif tertinggi pada tahun 2013 adalah Rokan Hilir dan Kota Pekanbaru masing-masing sebesar 77,9\% (Profil Dinkes Provinsi Riau, 2013).

Data yang didapatkan di Dinas Kesehatan Kota Pekanbaru data terbanyak ibu bersalin terdapat di Puskesmas Sudiomolyo Pekanbaru dengan jumlah persalinan 2800 orang. BPM Khairani Asnita termasuk dalam wilayah Puskesmas Sudiomolyo, yang mana BPM Khairani Asnita ini adalah salah satu BPM yang selalau melakukan program IMD pada ibu yang bersalin normal. Data 6 bulan terakhir 1 juli 2015 - 25 desember 2015 di dapatkan 60 orang yang bersalin di BPM Khairani Asnita.

Berdasarkan studi pendahuluan pada bulan Desember 2015 di BPM Khairani Asnita, di dapatkan hasil dari 20 orang yang melahirkan seluruhnya berhasil melakukan IMD akan tetapi hanya 3-5 orang yang memberikan ASI eksklusif sedangkan selebihnya melanjutlan dengan susu formula.

\section{METODOLOGI PENELITIAN}

Jenis penelitian adalah analitik kuantitatif dan bertujuan untuk mengetahui "hubungan pelaksanaan IMD dan sikap ibu terhadap pemberian ASI eksklusif di BPM Khairani Asnita Tahun 2015".

Desain penelitian cross sectional yaitu pengumpulan data yang menyakut variabel independen pelaksanaan IMD, sikap ibu, dukungan suami dan usia ibu terhadap pemberian ASI Ekslusif dan dependen pelaksanan IMD yang dikumpulkan dalam waktu yang bersamaan, di BPM Khairani Asnita Pekanbaru Tahun 2015.

Penelitian dilakukan di BPM Khairani Asnita dimulai pada Februari-Maret Tahun 2016. Populasi penelitian ini adalah ibu-ibu yang bersalin di BPM Khairani Asnita dan dilakukan IMD dengan usia bayi 16-12 bulan yang berjumlah 60 orang. Sampel dalam penelitian ini merupakan seluruh populasi. Teknik pengambilan sampel menggunakan teknik total sampling. Dan analisa data bivariat dengan uji chisquare test.

Dalam analisis data digunakan analisa Univariat dan analisa Bivariat. ( $p$ value $<0,05$ ).

\section{HASIL DAN PEMBAHASAN} Analisa Bivariat

a. Hubungan Keberhasilan IMD dengan Pemberian ASI Ekslusif

Dari hasil penelitian diketahui bahwa dari 60 responden, 37 responden yang melakukan IMD mayoritas memberikan ASI ekslusif sebesar 26 responden $(70,2 \%)$. Setelah dilakukan uji statistik dengan chi squaretest, maka diperoleh nilai $p$ value adalah $0,007(\mathrm{p}<0,05)$, yang berarti bahwa ada hubungan antara keberhasilan IMD dengan pemberian ASI ekslusif di BPM Khairani Asnita Pekanbaru Tahun 2015. Dan mempunyai nilai $\mathrm{OR}=4,432$ yang berarti ibu yang melakukan IMD 4 kali lebih banyak memberikan ASI eksklusif daripada ibu yang tidak melakukan IMD yang dapat dilihat dari tabel dibawah: 
Tabel 1

Hubungan Keberhasilan IMD dengan Pemberian ASI Ekslusif Di BPM Khairani Asnita tahun 2015

\begin{tabular}{llllllllll}
\hline \multirow{2}{*}{ Keberhasilan IMD } & \multicolumn{4}{l}{ Pemberian ASI Ekslusif } & \multicolumn{7}{c}{ Uji Statistik } \\
\cline { 2 - 9 } & \multicolumn{1}{l}{ Tidak } & Ya & & CI & & & \\
\cline { 2 - 9 } & F & $\%$ & F & $\%$ & F & $\%$ & P value & OR 95\% & \\
\hline Tidak & 15 & 25 & 8 & 13,3 & 23 & 38,3 & & 4,432 & $(1,460-$ \\
Ya & 11 & 18,3 & 26 & 43,3 & 37 & 61,7 & 0,007 & $13,455)$ & \\
Total & 26 & 43,3 & 34 & 56,7 & 60 & 100 & & & \\
\hline
\end{tabular}

b. Hubungan Sikap Ibu dengan Pemberian ASI Ekslusif

Dari hasil penelitian diketahui bahwa dari 60 responden, 39 responden yang bersikap positif mayoritas memberikan ASI ekslusif sebesar 34 responden $(87,2 \%)$. Setelah dilakukan uji statistik dengan chi squaretest, maka diperoleh nilai $p$ value adalah $0,000(\mathrm{p}<0,05)$, yang berarti bahwa ada hubungan antara sikap ibu dengan pemberian ASI ekslusif di BPM Khairani Asnita Pekanbaru Tahun 2015. Dan mempunyai nilai $\mathrm{OR}=7,800$ yang berarti ibu yang memiliki sikap positif 8 kali lebih banyak memberikan ASI eksklusif daripada ibu yang memiliki sikap negatif yang dapat dilihat dari tabel di bawah ini:

Tabel 2

Hubungan Sikap Ibu dengan Pemberian ASI Ekslusif

Di BPM Khairani Asnita tahun 2015

\begin{tabular}{|c|c|c|c|c|c|c|c|c|c|c|}
\hline \multirow{2}{*}{\multicolumn{2}{|c|}{ Sikap Ibu }} & \multicolumn{6}{|c|}{ Pemberian ASI Ekslusif } & \multirow{2}{*}{\multicolumn{2}{|c|}{ Uji Statistik }} & \\
\hline & & \multicolumn{2}{|c|}{ Tidak } & \multicolumn{2}{|r|}{$\mathrm{Ya}$} & \multicolumn{2}{|c|}{ Total } & & & \\
\hline & & $\mathrm{F}$ & $\%$ & $\mathrm{~F}$ & $\%$ & $\mathrm{~F}$ & $\%$ & $\mathrm{P}$ value & 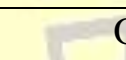 & \\
\hline Negatif & 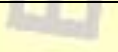 & 21 & 35 & 0 & 0 & 21 & 35 & 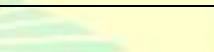 & 800 & \\
\hline Positif & 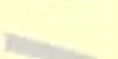 & 5 & 8,3 & 34 & 56,7 & 39 & & 0,000 & 800 & 3,44 \\
\hline Total & 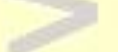 & 26 & 43,4 & 34 & 56,7 & 60 & 100 & & & \\
\hline
\end{tabular}

c. Hubungan Dukungan Suami dengan

Pemberian ASI Ekslusif

Dari hasil penelitian diketahui bahwa dari 60 responden, 29 responden yang mendapatkan dukungan suami mayoritas memberikan ASI ekslusif sebesar 22 responden (75,8\%). Setelah dilakukan uji statistik dengan chi squaretest, maka diperoleh nilai p-value adalah 0,004 $(\mathrm{p}<0,05)$, yang berarti bahwa ada hubungan

\section{Tabel 3}

Hubungan Dukungan Suami dengan Pemberian ASI Ekslusif

Di BPM Khairani Asnita tahun 2015

\begin{tabular}{|c|c|c|c|c|c|c|c|c|}
\hline \multirow{3}{*}{ Dukungan Suami } & \multicolumn{6}{|c|}{ Pemberian ASI Ekslusif } & \multirow{2}{*}{\multicolumn{2}{|c|}{ Uji Statistik }} \\
\hline & \multicolumn{2}{|c|}{ Tidak } & \multicolumn{2}{|c|}{ Ya } & \multicolumn{2}{|c|}{ Total } & & \\
\hline & $\mathrm{F}$ & $\%$ & $\mathrm{~F}$ & $\%$ & $\mathrm{~F}$ & $\%$ & $\mathrm{P}$ value & OR 95\% \\
\hline Tidak & 19 & 31,7 & 12 & 20 & 31 & 51,7 & \multirow{3}{*}{0,004} & \multirow{3}{*}{$\begin{array}{r}4,796(1,630- \\
15,192)\end{array}$} \\
\hline Ya & 7 & 11,7 & 22 & 36,7 & 29 & 48,3 & & \\
\hline Total & 26 & 43,3 & 34 & 56,7 & 60 & 100 & & \\
\hline
\end{tabular}

antara dukungan suami dengan pemberian ASI ekslusif di BPM Khairani Asnita Pekanbaru Tahun 2015. Dan mempunyai nilai OR $=4,796$ yang berarti ibu yang mendapatkan dukungan suami 5 kali lebih banyak memberikan ASI eksklusif daripada ibu yang tidak mendapatkan dukungan suami yang dapat dilihat dari tabel di bawah ini: 
d. Hubungan Umur Ibu dengan Pemberian ASI Ekslusif

Dari 60 responden, 28 responden yang berumur 20-35 tahun mayoritas memberikan ASI ekslusif yaitu sebesar 20 responden $(71,4 \%)$. Setelah dilakukan uji statistik dengan chi squaretest, maka diperoleh nilai $p$-value adalah $0,031(\mathrm{p}<0,05)$, yang berarti bahwa ada hubungan antara umur ibu dengan pemberian ASI ekslusif di BPM Khairani Asnita Pekanbaru Tahun 2015. Dan mempunyai nilai $\mathrm{OR}=3,214$ yang berarti ibu yang berumur 20-35 tahun 3 kali lebih banyak memberikan ASI eksklusif daripada ibu yang berumur $<20$ atau $>35$ tahun yang dapat dilihat pada tabel berikut:

\section{Tabel 4}

Hubungan Umur Ibu dengan Pemberian ASI Ekslusif

Di BPM Khairani Asnita tahun 2015

\begin{tabular}{ccccccccc}
\hline \multirow{2}{*}{ Umur Ibu } & \multicolumn{4}{c}{ Pemberian ASI Ekslusif } & \multicolumn{2}{c}{ Uji Statistik } \\
\cline { 2 - 7 } & \multicolumn{2}{c}{ Tidak } & \multicolumn{2}{c}{ Ya } & \multicolumn{2}{c}{ Total } & & OR 95\% \\
\cline { 2 - 7 } & F & $\%$ & F & $\%$ & F & $\%$ & P value & \\
\hline$<20$ atau $>35$ th & 18 & 30 & 14 & 23,3 & 32 & 53,3 & & \\
$20-35$ th & 8 & 13,3 & 20 & 33,3 & 28 & 46,7 & 0,031 & $3,214(1,095-9,437)$ \\
Total & 26 & 43,3 & 34 & 56,7 & 60 & 100 & & \\
\hline
\end{tabular}

a. Hubungan Keberhasilan IMD Dengan Pemberian ASI Ekslusif.

Berdasarkan hasil penelitian dapat diketahui bahwa dari 60 responden, 37 responden yang melakukan IMD mayoritas memberikan ASI ekslusif sebesar 26 responden (70,2\%). Setelah dilakukan uji statistik dengan chi squaretest, maka diperoleh nilai $p$-value adalah 0,007 $(\mathrm{p}<0,05)$, yang berarti bahwa ada hubungan antara keberhasilan IMD dengan pemberian ASI ekslusif di BPM Khairani Asnita Pekanbaru Tahun 2015. Dan mempunyai nilai $\mathrm{OR}=4,432$ yang berarti ibu yang melakukan IMD 4 kali lebih banyak memberikan ASI eksklusif daripada ibu yang tidak melakukan IMD.

IMD (early initiation) atau permulaan menyusu dini adalah bayi mulai menyusu sendiri segera setelah lahir. Cara bayi melakukan Inisiasi menyusu dini dinamakan the breast crawl atau merangkak mencari payudara. Setidaknya dalam waktu satu jam bayi baru lahir segera dikeringkan dan diletakan diperut ibu dengan kontak kulit ke kulit (saleha, 2009).

Peran tenaga kesehatan dalam IMD adalah penting. Dengan IMD, ibu semakin percaya diri untuk tetap memberikan ASInya sehingga tidak merasa perlu untuk memberikan makanan/minuman apapun kepada bayi karena bayi bisa nyaman menempel pada payudara ibu segera setelah lahir (Saleha, 2009).
Pelaksanaan IMD pada tahap bayi dapat menyusu segera membuat bayi mendapat pengalaman menyusui sedini mungkin sehingga pada jam dan hari - hari berikutnya bayi sudah terlatih untuk menghisap payudara ibunya, seiring dengan bayi menyusui pada ibu membuat kelenjar payudara terangsang untuk memproduksi ASI lebih banyak sehingga permintaan air susu oleh bayi sesuai dengan persediaan air susu dari ibu. Bila ibu memiliki pengetahuan yang baik tentang pelaksaan IMD dan manfaat pemberian ASI Ekslusif, maka hal ini dapat membuat ibu memberikan ASI Ekslusif pada bayinya.

Bayi yang di beri kesempatan untuk menyusu dini akan mempunyai kesempatan lebih berhasil menyusui eksklusif dan mempertahankan menyusu daripada yang menunda dari yang menyusu dini ( Jenny \& J.s. Sondakh, 2013).

Penelitian ini sesuai dengan hasil penelitian Ida (2011) faktor-faktor yang berhubungan dengan pemberian ASI ekslusif enam bulan di wilayah kerja puskesmas kemiri muka kota Depok tahun 2011, diketahui terdapat hubungan antara IMD dengan perilaku pemberian ASI Ekslusif dengan OR 2.368 (95\% CI 1,174-4,780) yang berarti ibu yang melakukan IMD 2.368 kali berperilaku memberikan ASI Ekslusif dibandingan ibu yang tidak melakukan IMD. 
Berdasarkan penjelasan diatas, peneliti berasumsi bahwa dengan berhasilnya IMD yang dilakukan membuat bayi jadi terbiasa menghisap puting susu, membuat bayi menjadi terbiasa menyusu dengan ASI sehingga ASI yang dikeluarkan bisa lebih meningkat jumlahnya karena semakin sering dihisap bayi. Jadi, jika ASI nya yang keluar sudah banyak, ibu akan semangat memberikan ASI eksklusif karena jika tidak diberikan terus-menerus ibu takut payudaranya bengkak karena ASInya menumpuk. Selain itu karena sudah berhasil melakukan IMD maka tidak ada lagi kecemasan ibu untuk tidak dapat menyusui bayinya secara eksklusif, karena ia sudah melihat sendiri bahwa anaknya sudah puas hanya dengan diberikan ASI tanpa tambahan makanan atau minuman apapun. Selain itu ibu yang berhasil melakukan IMD juga melihat sendiri manfaat dari ASI yang diberikan terhadap bayinya, yang menjadikan bayinya lebih kuat daripada bayi dengan susu formula, secara otomatis ibu juga akan lebih yakin untuk terus memberikan ASI saja sampai anaknya berusia 6 bulan.

b. Hubungan Sikap Ibu Dengan Pemberian ASI Ekslusif

Berdasarkan hasil penelitian dapat diketahui bahwa dari 60 responden, 39 responden yang bersikap positif mayoritas memberikan ASI ekslusif sebesar 34 responden $(87,2 \%)$. Setelah dilakukan uji statistik dengan chi squaretest, maka diperoleh nilai $p$-value adalah 0,000 $(\mathrm{p}<0,05)$, yang berarti bahwa ada hubungan antara sikap ibu dengan pemberian ASI ekslusif di BPM Khairani Asnita Pekanbaru Tahun 2015. Dan mempunyai nilai OR $=7,800$ yang berarti ibu yang memiliki sikap positif 8 kali lebih banyak memberikan ASI eksklusif daripada ibu yang memiliki sikap negatif.

Pembentukan dan perubahan sikap tidak terjadi dengan sendirinya. Sikap terbentuk dalam hubungan suatu obyek, orang, kelompok, lembaga, nilai melalui hubungan antar individu, hubungan di dalam kelompok, komunikasi surat kabar, buku, poster, radio, televisi, dan sebagainya (Azwar, 2013).

Seorang ibu yang tidak pernah mendapatkan nasehat atau pengalaman, penyuluhan tentag ASI dan seluk beluknya dari orang lain, maupun dari buku-buku bacaan dapat mempengaruhi sikapnya pada saat ibu tersebut harus menyusui. Sikap seseorang dipengaruhi oleh pengetahuan yang dipunyainya dan ia akan memberikan sikap negatif terhadap ASI, jika pengetahuan tentang hal itu kurang (Prasetyono, 2012).

Ibu yang berhasil menyusui anak sebelumnya dengan pengetahuan dan pengalaman cara pemberian ASI secara baik dan benar akan menunjang laktasi berikutnya. Sebaliknya, kegagalan menyusui pada masa lalu akan mempengaruhi sikap seorang ibu terhadap penyusuan sekarang. Dalam hal ini perlu ditumbuhkan motivasi dalam diri ibu dalam menyusui anaknya. Pengalaman masa kanakkanak, pengetahuan tentang ASI, nasehat, penyuluhan, bacaan, pandangan dan nilai-nilai yang berlaku di masyarakat akan membentuk sikap ibu yang positif terhadap menyusui (Rosita, 2008).

Ini sesuai dengan hasil penelitian Yuliarti (2008) hubungan pengetahuan dan sikap ibu dengan perilaku pemberian ASI eksklusif di Puskesmas Sambungmacan I Kabupaten Sragen yang menyatakan bahwa ada hubungan yang bermakna antara sikap ibu dengan pemberian ASI eksklusif ( $p$ < 0.05) dengan CI 95\%.

Berdasarkan penjelasan diatas peneliti berasumsi bahwa sikap yang didapat ibu kebanyakan diperoleh lewat pengalaman yang dapat menimbulkan pengaruh terhadap perilaku. Pengaruhnya itu biasanya itu terlihat saat ibu berada dalam kondisi yang sesuai dengan pengamalamannya itu, termasuk tentang menyusui bayi. Banyak ibu yang sudah pernah memiliki anak dan anak sebelumnya yang tidak diberi ASI saja sampai usia 6 bulan, cenderung juga tidak memberikan ASI eksklusif pada bayi berikutnya karena menganggap anak sebelumnya saja bisa sehat terus tanpa harus ASI eksklusif, sehingga ibu menganggap ASI eksklusif tidak terlalu mempengaruhi kesehatan bayinya. Ada juga beberapa ibu yang memilih tidak memberikan ASI eksklusif karena kurangnya pengetahuan ibu tentang pentingnya ASI bagi bayi dan tidak paham bahwa bayi 0 sampai 6 bulan itu kebutuhannya hanya bisa dipenuhi oleh 
ASI, hal itu membuat ibu merasa kalau diberikan ASI saja bayi akan cepat lapar sehingga ada beberapa ibu yang memilih memberikan makanan pendamping ASI sebelum bayi berusia 6 bulan. Semua penyebab itu dapat diatasi dengan meminta ibu untuk lebih banyak lagi mencari informasi terkait baik dari membaca ataupun bertanya pada ahlinya, serta mengikuti penyuluhan tentang perawatan bayi.

c. Hubungan Dukungan Suami Dengan Pemberian ASI Ekslusif

Berdasarkan hasil penelitian dapat diketahui bahwa dari 60 responden, 29 responden yang mendapatkan dukungan suami mayoritas memberikan ASI ekslusif sebesar 22 responden (75,8\%). Setelah dilakukan uji statistik dengan chi squaretest, maka diperoleh nilai $p$-value adalah $0,004(p<0,05)$, yang berarti bahwa ada hubungan antara dukungan suami dengan pemberian ASI ekslusif di BPM Khairani Asnita Pekanbaru Tahun 2015. Dan mempunyai nilai $\mathrm{OR}=4,796$ yang berarti ibu yang mendapatkan dukungan suami 5 kali lebih banyak memberikan ASI eksklusif daripada ibu yang tidak mendapatkan dukungan suami.

Hasil penelitian ini sejalan dengan teori Prasetyo (2010) yang mengatakan bahwa dukungan orang terdekat khusunya suami sangat dibutuhkan dalam mendukung ibu selama memberikan ASI-nya sehingga memunculkan istilah breastfeeding father atau ayah menyusui. Jika ibu merasa didukung, dicintai, dan diperhatikan maka akan muncul emosi positif yang akan meningkatkan produksi hormon oksitosin sehingga produksi ASI pun lancar.

Suami dan keluarga berperan dalam mendorong ibu untuk memberikan ASI kepada bayinya. Dukungan tersebut dapat memperlancar refleks pengeluaran ASI karena ibu mendapat dukungan secara psikologis dan emosi (Pertiwi, 2012).

Hal ini sesuai dengan penelitian Hilala (2013) tentang faktor-faktor yang berhubungan dengan pemberian asi ekslusif di wilayah Kerja Puskesmas Tuladenggi Kecamatan Telaga Biru tahun 2013 yang menyebutkan diperoleh nilai X2 hitung $(5,824)>\mathrm{X} 2$ tabel $(3,841)$ dan nilai Pvalue $(0,016)<\alpha(0,05)$ menggambarkan ada hubungan yang bermakna antara dukungan orang terdekat dengan pemberian ASI eksklusif.

Berdasarkan penjelasan diatas peniliti berasumsi bahwa dalam menyusui atau memberikan makanan tambahan sebelum bayi berusia enam bulan kebanyakan yang dipengaruhi oleh anjuran dari keluarga terutama nenek dan keluarga terdekat yang ikut merawat bayi karena mereka merasa memiliki pengalaman atau pengetahuan tentang hal itu. Terutama bagi ibu primigravida, ia lebih mendegarkan anjuran dari orang terdekatnya daripada tenaga kesehatan karena menurutnya orang terdekatnya jauh lebih tau apa yang terbaik untuknya dan anaknya. Ada juga beberapa orang suami yang malah menyarankan agar bayi diberikan susu formula saja karena menurutnya kandungan gizi susu formula sudah dapat memenuhi kebutuhan bayinya. Padahal seharusnya suami memahami bahwa proses menyusui itu bukan hanya kegiatan antara ibu dan bayi, tetapi ayah juga memiliki peran yang sangat penting dan dituntut keterlibatannya. Bagi ibu menyusui, suami merupakan orang paling dekat yang diharapkan untuk selalu ada di samping ibu dan siap memberikan bantuan kapanpun dibutuhkan. Ibu yang berhasil melakukan ASI eksklusif rata-rata mendapatkan dukungan dari suami dan keluarga terdekatnya. Kebanyakan suami mereka membantu ibu mencari informasi dari internet tentang seberapa pentingnya ASI eksklusif untuk bayi, mencari cara agar penampilan istri tetap indah tanpa mengganggu program ASI eksklusifnya, serta selalu membantu istri dalam mengurus anak sehingga ibu merasa bahwa suaminya sangat peduli tentang kesehatannya dan anak mereka sehingga ibu bisa sangat percaya diri untuk tetap melakukan ASI eksklusif karena merasa ia sangat diperhatikan oleh orang yang ia sayang. Harusnya semua suami juga memahami hal yang sudah dilakukan oleh sebagian suami lainnya, dapat memahami bahwa peran suami siaga seharusnya bukan hanya saat istrinya hamil tetapi juga saat istrinya melahirkan dan selama istrinya menyusui.

d. Hubungan Umur Ibu Dengan Pemberian ASI Ekslusif 
Berdasarkan hasil penelitian diatas diketahui bahwa dari 60 responden, 28 responden yang berumur 20-35 tahun mayoritas memberikan ASI ekslusif yaitu sebesar 20 responden $(71,4 \%)$. Setelah dilakukan uji statistik dengan chi squaretest, maka diperoleh nilai $p$-value adalah $0,031(\mathrm{p}<0,05)$, yang berarti bahwa ada hubungan antara umur ibu dengan pemberian ASI ekslusif di BPM Khairani Asnita Pekanbaru Tahun 2015. Dan mempunyai nilai OR $=3,214$ yang berarti ibu yang berumur 20-35 tahun 3 kali lebih banyak memberikan ASI eksklusif daripada ibu yang berumur $<20$ atau $>35$ tahun.

Produksi ASI berubah seiring dengan perubahan usia. Ibu yang berusia 19-23 tahun umumnya memiliki produksi ASI yang lebih dibanding ibu yang berusia lebih tua. Hal ini terjadi karena adanya pembesaran payudara setiap siklus ovulasi mulai awal terjadinya menstruasi sampai usia 30 tahun, namun terjadi degenerasi payudara dan kelenjar penghasil ASI (alveoli) secara keseluruhan setelah usia 30 tahun (Pertiwi, 2012).

Umur ibu sangat menentukan kesehatan maternal karena berkaitan dengan kondisi kehamilan, persalinan, dan nifas, serta cara mengasuh juga menyusui bayinya. Ibu yang berumur kurang dari 20 tahun masih belum matang dan belum siap secara jasmani dan sosial dalam menghadapi kehamilan, persalinan, serta dalam membina bayi yang akan dilahirkan Sedangkan ibu yang berumur 20-35 tahun, menurut (Arini, 2012), sedangkan ibu yang berumur 20-35 tahun secara reproduksi telah matang dan telah mampu memecahkan masalahmasalah yang dihadapinya, terutama dalam menghadapi kehamilan, persalinan, nifas, dan merawat bayinya nanti (Yanti, 2012).

Penelitian ini sesuai dengan hasil penelitian Hilala (2013) tentang faktor-faktor yang berhubungan dengan pemberian asi ekslusif di wilayah Kerja Puskesmas Tuladenggi Kecamatan Telaga Biru tahun 2013 diperoleh nilai X2 hitung $(19,374)>\mathrm{X} 2$ tabel $(3,841)$ dan nilai Pvalue $(0,000)<\alpha(0,05)$ menggambarkan ada hubungan yang bermakna antara usia ibu dengan pemberian ASI eksklusif.
Berdasarkan penjelasan tersebut peniliti berasumsi bahwa umur ibu yang berada pada usia reproduksi yaitu 20-35 tahun cenderung lebih banyak yang paham tentang perawatan bayinya termasuk pemberian ASI eksklusif. Hal itu karena ada berbagai faktor seperti persiapan mental yang lebih matang, buku-buku atau sumber bacaan yang berkaitan, atau juga dari hasil bertanya pada dokter kandungan atau bidan. Sedangkan untuk ibu yang berusia $<20$ tahun mayoritas masih belum mempunyai banyak persiapan untuk mempunyai anak termasuk untuk segi mental sehingga lebih mempercayai apapun yang berhubungan dengan dirinya dan bayinya pada orang terdekatnya terutama ibunya karena menganggap mereka pasti mengetahui banyak hal tentang cara merawat dan membesarkan bayi, padahal kebanyakan dari orang tua mereka ternyata dulunya tidak memberikan ASI sampai anak berusia 6 bulan karena menganggap ASI saja tidak dapat membuat bayi kenyang. Begitu pula untuk ibu yang > 35 tahun, rata-rata lebih banyak menganggap dirinya lebih berpengalaman dari orang sekitarnya ataupun tenaga kesehatan, padahal tidak semua yang terjadi pada pengalamannya itu merupakan hal yang benar. Tidak baik jika ibu menganggap dirinya jauh lebih paham hanya karena merasa sudah berpengalaman. Harusnya ibu mengetahui manfaat ASI terlebih dahulu seperti ibu-ibu lainnya yang sudah lebih dulu memahaminya, jangan sampai hanya karena menganggap pengalamannya lebih baik daripada teori yang ada, ibu jadi mengabaikan kebutuhan bayinya yang padahal sampai berusia 6 bulan hanya dapat dipenuhi oleh ASI. Diharapkan pada ibu menyusui lainnya untuk saling bertukar informasi agar dapat saling memberitahu tentang perawatan bayi yang baik.

\section{KESIMPULAN DAN SARAN}

Dari pembahasan yang telah disampaikan dapat disimpulkan sebagai berikut:

a. Ada hubungan yang signifikan antara sikap ibu dengan pemberian ASI eksklusif di BPM Khairani Asnita tahun 2015 dengan hasil uji statistik menggunakan chisquare test didapatkan pvalue 0,000 dengan OR 7,800. 
b. Ada hubungan antara dukungan suami dengan pemberian ASI eksklusif di BPM Khairani Asnita tahun 2015 dengan hasil uji statistik menggunakan chisquare test didapatkan pvalue 0,004 dengan OR 4,796.

c. Ada hubungan antara keberhasilan IMD dengan pemberian ASI eksklusif di BPM Khairani Asnita tahun 2015 dengan hasil uji statistik menggunakan chisquare test didapatkan pvalue 0,007 dengan OR 4,432.

d. Ada hubungan antara umur ibu dengan pemberian ASI eksklusif di BPM Khairani Asnita tahun 2015 dengan hasil uji statistik menggunakan chisquare test didapatkan pvalue 0,031, dengan OR 3,214.

\section{SARAN}

a. Diharapkan bagi seluruh tenaga kesehatan khususnya BPM Khairani Asnita untuk selalu memberikan informasi kepada masyarakat mengenai pemberian ASI eksklusif dan melakukan pendampingan bagi ibu menyusui sampai bayi berusia 6 bulan .

b. Bagi institusi pendidikan kesehataan dalam memberikan dukungan program pemberian ASI eksklusif selama 6 bulan, setiap mahasiwa yang praktik dilapangan wajib memberikan asuhan atau pendampingan pada ibu menyusui sampi bayi berusia 6 bulan dan memberikan penyuluhan tentang pentingnya ASI eksklusif selama bayi berusia 0-6 bulan .

\section{DAFTAR PUSTAKA}

Anonim. 2005. Program ASI Eksklusif hingga Bayi Enam Bulan. http://situs.kesrepro.info/kia/agu/2005/ki ao/htm. Accessed in Augustus 2005.

Ariani, H, (2012). Asi Ekslusif, Bandung: Khanzanah Intelektual.

Hilala, Agnes (2013). Faktor-Faktor Yang Berhubungan Dengan Pemberian Asi Ekslusif Diwilayah Kerja Puskesmas Tuladenggi Kecamatan Telaga Biru Tahun 2013. (https://www.scribd.com> mobile > doc, diakses 2014).

Ida, (2011). Faktor-Faktor yang Berhubungan dengan Pemberian ASI Ekslusif Enam Bulan di wilayah Kerja Puskesmas
Kemiri Muka Kota Depok Tahun 2011. (https://www.scribd.com> mobile > doc, diakses November 2012).

IBI, (2005). 50 Ikatan Bidan Indonesia, Jakarta: PP IBI. 2011. Tesis FKM Universitas Indonesia.

Kalnins, D, (2010). Baby Feeding, Jakarta: Ktalog Dalam Terbitan.

Notoatmodjo, S, (2010). Metologi Penelitian Kesehatan, Jakarta: PT Rineka Cipta. Depkes (2011).

Nurasiah, dkk, (2012). Asuhan Persalinan Normal Bagi Bidan, Jakarta.

Prawidrohardjo, S. (2007). Ilmu Kebidanan, Jakarta: PT Bina Pustaka.

Prasetyono, (2012). Buku Pintar ASI Ekslusif, Yogyakarta: Diva Press.

PP No.33, (2013). Insiasi Menyusu Dini \& Pemberian ASI Ekslusif, Jakarta.

Pertiwi, (2013). Ilmu Kebidanan, Jakarta: Yayasan Bina pustaka.

Roesli, U. (2008). Inisiasi Menyusu Dini Plus ASI Ekslusif. Jakarta: Pustaka Bunda.

Rosita (2008). Air SuSu Ibu, Yogyakarta: ArRuzz Media.

Rohani, dkk, (2011). Asuhan Kebidanan Pada Masa Persalinan, Jakarta: Salembah Medika.

Saleha, S (2009). Asuhan Kebidanan pada Masa Nifas, Jakarta: Salembah Medika.

Shinta, dkk, (2010), Asuhan Kebidanan Masa Persalinan, Yogyakarta: Graha Ilmu.

Susistyowati, S. L, (2010). Majalah Informasi Dan Kesehatan, edisi 3. (2010): Pusat Promosi Kesahatan Kementrian Kesehatan Republik Indonesia.

Suryaningsih. M, (2013). Faktor-Faktor yang Mempengaruhi Keberhasilan ASI Ekslusif.

Selvi, juli, (2013). Pemberian ASI Ekslusif pada Ibu yang Melaksanakan IMD di RSUD Arifin Achmad Provinsi Riau Tahun 2013. Tesis Stikes Hang Tuah Pekanbaru.

Yuliarti, iin dwi, (2008). Hubungan Pengetahuan Dan Sikap Ibu Dengan Perilaku Pemberian Asi Eksklusif di Puskesmas Sambungmacan I, Kabupaten Sragen. 
(https://www.scribd.com> mobile > doc, diakses 2010).

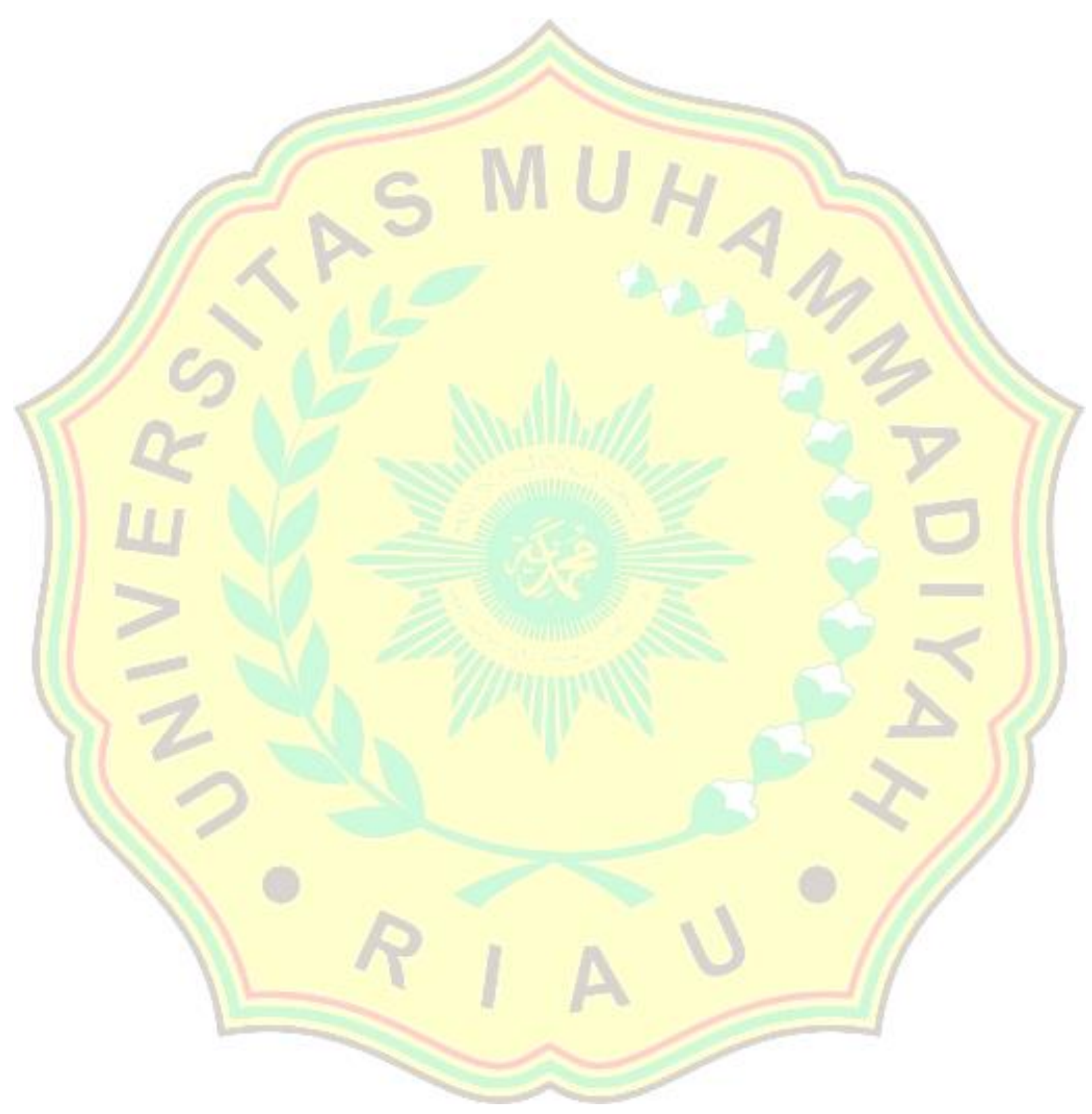

